\title{
Kolejny numer czasopisma
}

„Heteroglossia. Studia kulturoznawczo-filologiczne”, Bydgoszcz 2013, nr 3 (2013), $172 \mathrm{~s}$.

To już trzeci numer bardzo interesującego czasopisma „Heteroglossia. Studia kulturoznawczo-filologiczne" ${ }^{1}$ wydawanego przez Instytut Kulturoznawstwa i Katedrę Lingwistyki Stosowanej Wyższej Szkoły Gospodarczej w Bydgoszczy. W omawianym tomie występują trzy działy. Literaturoznawstwo, gdzie są opublikowane trzy teksty (jeden w języku ukraińskim); Językoznawstwo z sześcioma artykułami (2 w języku angielskim i $2 \mathrm{w}$ języku rosyjskim) i Kulturoznawstwo, zawierające cztery materiały w języku polskim.

1 „Heteroglossia. Studia kulturoznawczo-filologiczne”, red. W. Piłat, Bydgoszcz 2013, nr 3 (2013), 172 s. 
Artykuł Ireny Betko (Olsztyn) „Мотиви психофічного дозрівання жінкі в інтерпретаціi украінских письменників-постмодерністів" (s. 9-21) otwiera dział prac literaturoznawczych i jest poświęcony literaturze ukraińskiej końca XX-początku XXI wieku, w szczególności tym twórcom, których uwaga концентруеться на аспектах дівочого тіла (s. 9). Autorka pokazuje twórczość ukraińskich prozaików-postmodernistów, przeprowadza analizę прозових творів Оксани Забужко, Евгеніі Кононенко, Наталки Сняданко, а також Юрія Андруховича, Олександра Ірванця (s. 9) i innych pisarzy, zwracając uwagę na rolę i znaczenie wychowania młodych dziewcząt $\mathrm{w}$ rodzinie, na процес фізичного $i$ духовного формування доростаючоі дівчини, który у переважній більшості випадків точиться у контексті сімейноі педагогіки, що носить більш альбо менш інвазійний характер (s. 11).

Walenty Piłat (Olsztyn, s. 23-27) poświęcił swój tekst współczesnej dramaturgii rosyjskiej, analizując utwory wybranych twórców (Aleksander Burawski, Michał Szatrow, Ludmiła Pietruszewska, Władimir Arro, Aleksiej Kazancew, Aleksandr Galin, Ludmiła Razumowskaja, przedstawiciele „,szkoły” Nikołaja Kolady i in.) z punktu widzenia ich stosunku do transformacji ustrojowych. Rozpad Zwiazku Radzieckiego, - nie bez racji stwierdza Autor - wywolat u pisarzy nie tylko entuzjazm $i$ optymizm, ale stat sie też źródtem postaw krytycznych wobec nowych realiów (s. 25-26).

Na podstawie twórczości Marka Ałdanowa, Niny Berberowej i Borysa Zajcewa Patryk Witczak (Bydgoszcz, s. 29-41) pokazuje podejście do tematyki historycznej w prozie pisarzy pierwszej fali emigracji rosyjskiej, podkreślając tematyczne i problemowe bogactwo i różnorodność utworów, zróżnicowanie gatunków literackich (powieść historyczna, biograficzna, autobiograficzna), ważność tematu historii dla „twórczości emigrantów pierwszej fali rosyjskiego uchodźctwa" (s. 39).

W części Językoznawczej zamieszczone zostały dwa teksty w języku angielskim, w których Autorzy przedstawili problemy współczesnej gramatyki angielskiej. Piotr Cap (Łódź-Bydgoszcz) w artykule „Pragmatic perspectives on teaching English as a foreign language” (s. 45-51), a Wiktor Pskit (Bydgoszcz- -ódź) w tekście „The position of adjectival modifiers in English and Polish noun phrases" (s. 69-79).

W języku rosyjskim zaprezentowane zostały „Метафора и языковая картина мира" (Гульнар Окусхановна Мухаметкалиева, Казахский национальный технический университет, s. 61-68), a także „Модальное микрополе возможности в русском и польском языках" (Светлана Ваулина, Екатерина Магдалинская, Калининград, s. 81-89), для анализа которых послужили разножанровые письменные источники современных русского и польского языков, прежде всего газетно-публицистические, научные и офичиально-деловые тексты, поскольку жанрово-стилистические особенности данных текстов с точки зрения реализачии в них модальности позволяет сделать определеннье обобщения на уровне языка (s. 82).

Irena Kudlińska (Bydgoszcz, s. 53-60) przedstawiła znaczenie i rolę ujednolicenia kształcenia i poziomu biegłości językowej w całej Europie na podstawie międzynarodowych certyfikatów TELC; Sylwia A. Wiśniewska (Świecie, s. 91-108) zwróciła uwagę na wszystkie elementy i płaszczyzny współpracy pomiędzy nauczy- 
cielami języków obcych, a rodzicami uczniów na poziomie edukacji przed- i wczesnoszkolnej.

Tekst Miłosza Babeckiego "Mediatyzacja współczesnego teatru polskiego. Wybrane historyczne, ekonomiczne i technologiczne aspekty" (Olsztyn, s. 111-126) otwiera Kulturoznawstwo i jest poświęcony chronologicznie pokazanym przemianom w rozwoju teatru polskiego; Jacek Lindner (Bydgoszcz, s. 127-139) przedstawił rozwój prasy kulturalnej w regionie kujawsko-pomorskim po roku 1989; Marzena Sobczak-Michałowska (Bydgoszcz, s. 141-158) na podstawie istniejącej literatury przedmiotu oraz badań własnych przeprowadziła socjologiczną analizę międzypokoleniowych opinii na temat alternatywnych form życia w rodzinie; Szymon Żyliński (Olsztyn, s. 159-172) przedstawił genezę i rozwój zjawiska autostopu od początku jego istnienia ze szczegółowym uwzględnienie wpływu tej formy przemieszczania się w Wielkiej Brytanii na inne kraje. Jak zauważa Autor, autostop od zarania pelnit różnorakie funkcje: od życzliwego podwiezienia poprzez alternatywny transport wojenny do kontestacyjnych praktyk hipisów. Trudno sobie wyobrazić wspótczesny świat $i$ zachodzace $w$ nim przemiany bez swobody autostopowego przemieszczania (s. 170).

Jak się wydaje, kolejny numer czasopisma przyciąga uwagę swoją różnorodnością, ciekawymi tematami z literaturoznawstwa, metodyki i językoznawstwa, oryginalnym podejściem do różnorakich problemów kultury we współczesnym świecie, bogatą i różnicowaną bibliografią we wszystkich artykułach. Omawiana pozycja, niewątpliwe, może zainteresować wielu czytelników, jest godna polecenia zarówno dla wykładowców, badaczy, jak i studentów-filologów i studentów kulturoznawstwa.

Irena Rudziewicz

Olsztyn 